\title{
The Light to the Left: Conceptions of Social Justice Among Christian Social Studies Teachers
}

Paul Orlowski

\author{
University of Saskatchewan
}

\begin{abstract}
This article describes a study that took place in Saskatchewan, Canada, during 2013-2014. Ten practicing high school social studies teachers who self-identified as Christian answered an unsolicited invitation to participate in a qualitative study about the ways in which they think about social justice. Almost evenly split between Catholic and Protestant, female and male, and urban and rural, most participants were very progressive in their thinking about important economic and social issues. For example, all supported paying taxes and the social welfare state, and almost all supported gay rights and feminism. As well, an important emergent theme arose: The majority spoke about breaking from the teachings of their church if the teachings did not fit with contemporary society. All of them claimed that their faith influenced their thinking about social justice. The study challenges some secular notions about the values held by Christian social studies teachers. Situated in Canada, the study challenges American research findings about the political ideology and values of Christian social studies teachers.
\end{abstract}

Keywords: social studies education; teaching for social justice; controversial issues; teacher beliefs; Christian teaching

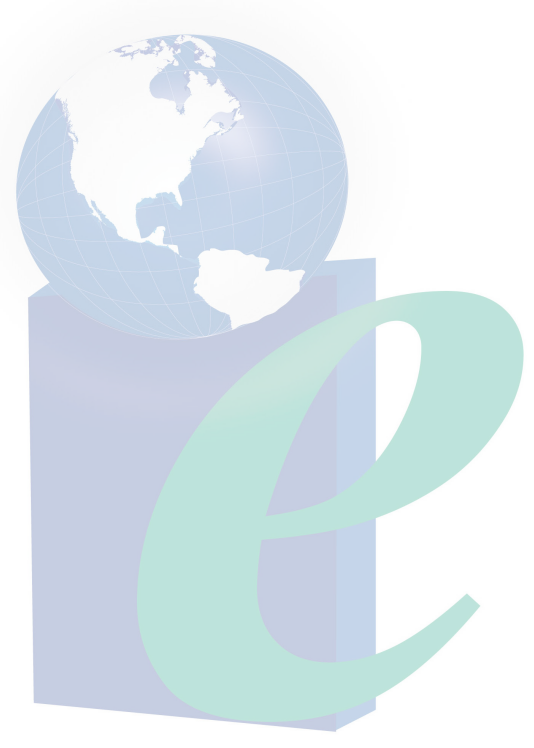




\section{The Light to the Left: Conceptions of Social Justice Among Christian Social Studies Teachers}

The educational problem is to find a way to respect religious teachings while reproducing in each generation the values, attitudes, and dispositions guaranteed by and for a liberal democracy. (Feinberg, 2006, p. xxi)

Although without consensus, there has been much support for the notion that social studies as a high school teaching subject should promote the values necessary to function and participate in a liberal democracy (Dewey, 1916; Feinberg, 2006; Kunzman, 2006b). To this end, social studies should help students develop a sincere respect for the Other, especially important in our increasingly diverse society. It should address a range of perspectives with the objective of striving for compromise and accommodation with an eye toward the common good (Kunzman, 2006a).

This article describes a study that explores the degree to which high school social studies teachers who self-identify as Christian think about the values of a liberal democracy. The study took place in 2013-2014 in Saskatchewan. Ten practicing high school social studies teachers who self-identified as Christian answered an unsolicited invitation to participate in a qualitative study about the ways in which they think about social justice.

There is little doubt that a person's faith mediates the way they see and act in the world. The majority of teachers in the public schools of Saskatchewan come from Christian backgrounds. Some empirical research has been done around teaching Bible courses in American public schools (Feinberg \& Layton, 2013). Moreover, there has been some research on the growing use of Bible curriculum in public schools (Chancey, 2007; Haynes, 2011). Studies that examine the influence of conservative Christianity in American social studies and civics classrooms have been published (James, 2010; Journell, 2011; Schweber, 2006). There is a dearth of research, however, that explores how social studies teachers think about social justice based on Christian principles of social justice. Moreover, very little research has been done that explores the values of Christian social studies teachers in Canada.

This situation inspired me to ask the following two related research questions in this study: How do practicing teachers of social studies who adhere to the Christian faith understand the term social justice? How do they claim that this understanding of social justice influences their teaching of values and perspectives on political issues?

\section{My Social Positionality}

This study was influenced by my own experience. I was raised Catholic in Toronto by immigrant parents, and did my entire K-13 schooling in Toronto's Catholic schools in the 1960s and 1970s. This was an interesting time and place to be a young Catholic: Vatican II was passed in 1965, and with this came a progressive orientation to Toronto's Catholic Churches and schools (Schmidt, 2007). I became politically conscious in high school through my faith with initiatives such as the Cesar Chavez-led campaign of the early 1970s to boycott California Grapes (Levy, 1975). By the 1980s, I had left the Catholic Church because my own political stances were becoming more progressive at the same time that the Church was moving back toward a staunch conservatism. Consequently, to a certain extent I inhabit both insider and outsider status in this study. My use of the term politically progressive implies that I support an 
inclusive society that supports human rights for everyone. Moreover, I consider it to be the government's role to intervene in a nation's economy to help those people who are experiencing economic marginalization.

It is noteworthy that I also inhabit insider and outsider status with the participants in terms of occupation. For 19 years I was a high school teacher in British Columbia, mostly teaching social science courses such as social studies and civic studies. I left the high school setting 11 years ago to become a full-time teacher educator. In both settings, the focus of my pedagogy has been on teaching for political consciousness.

\section{A Brief Overview of the Current Context in Saskatchewan}

Indigenous issues are a major concern in Saskatchewan, both from a social and an economic standpoint. ${ }^{1}$ The province is currently enjoying a period of unprecedented economic prosperity based on resource extraction, agriculture, and knowledge industries. This newfound prosperity, however, is not distributed evenly across racial lines: An overwhelming 57.9\% of First Nations children in Saskatchewan regularly go without some of the basic necessities of life (Douglas \& Gingrich, 2009). Indigenous youth will soon represent close to half of the students in the province's K-12 school system (Howe, 2011).

A large body of research suggests that the pervasive disadvantages experienced by Indigenous peoples in Saskatchewan emanate from, and are reflected in, poor educational achievement normalized by the legacy of colonialism, including a residential school policy that lasted for over a century with devastating effects still felt today (Battiste, 2013; Richards, 2008). In order to rectify this situation, the Saskatchewan Government created Treaty kits for every school in the province (Tupper, 2012). Each kit contains resources and unit plans for teachers in each grade from kindergarten to the 12th grade. Teachers are mandated to use these resources to educate students on Treaties and Indigenous perspectives.

The history of Saskatchewan has primarily been about settler and Indigenous society (Waiser, 2005). In recent years, however, Saskatchewan's population has also significantly increased because of immigration, predominantly from Europe and Asia. From 2002-2011, the province's immigration rate increased by 437 per cent (Government of Saskatchewan, 2011). Moreover, the number of young immigrants to Saskatchewan is expected to double from 2013 to 2023 (Elliott, 2014). This increase is clearly connected to the economic boom and low unemployment rates resulting from resource extraction.

The recent economic prosperity has seemingly altered the dominant political ideology of Saskatchewan. The province has a long history of socialist, social democratic, and liberal governments, and in 1962 became the first province in Canada to implement a fully public healthcare system (McGrane, 2011). In the recent past, however, Saskatchewan voters have overwhelmingly elected representatives from conservative-oriented parties at both the federal and provincial levels (Orlowski, 2015).

\section{Literature Review}

Political ideology is at the root of this study in that I examine the discourses used by the teachers through an ideological lens. Canadian politics have been dominated by three ideologies: conservatism, liberalism, and social democracy (Orlowski, 2011). For the purposes of this study, however, the binary of conservatism and progressivism will be used. In terms of social issues, 
and to a lesser extent on economic issues, liberalism and social democracy share many positions, all of which are progressive (Orlowski, 2011; Sadovnik, Cookson, \& Semel, 2013). It is important, however, not to conflate the ideologies of conservative Christians and progressive Christians with the ideologies of Canadian political parties.

\section{Progressivism and Conservatism in the Canadian Political Spectrum: A Brief Overview}

Although it is beyond the scope of this article to delve into the characteristics of liberalism and social democracy and their differences, it is fair to claim that both ideologies share similar positions on social issues (Orlowski, 2011). Progressive values include rights for marginalized groups such as Indigenous and LGBTQ communities, as well as a woman's right to choose and a disdain for capital punishment. Liberals and social democratic parties in Canada support these progressive values. Although they differ on economic issues, differences in how liberal and social democratic political parties in Canada support Keynesian economics vary only in degree. The progressive economic model in Canada supports the notion of state intervention in the economy to help groups falling through the cracks created by capitalism.

Moreover, conservatism in Canada is not a monolithic political ideology. However, for the purposes of this research there are some general traits associated with it. Support for wellentrenched traditional social hierarchies based on gender, class, and race is part of the conservative ideology. This is demonstrated by less financial support for affordable daycare and affordable housing, as well as full support for the federal temporary worker program that virtually negates the rights of workers brought in from non-Western nations. In economic terms, the notion of individual responsibility figures more prominently in conservatism than with the progressive perspective. Vestiges of the social welfare state remain in Canada, but the recent decade of governance by the Conservative Party of Canada has resulted in less social program funding and a decrease in the collective bargaining rights of workers (Orlowski, 2014, 2011).

On social issues, conservatism in Canada is not as far to the right as in the United Sates. For example, conservative governments in Canada do not attempt to repeal laws that support equal rights for LGBQT communities or gay marriage. Nor do they limit a woman's right to choose. They are, however, less supportive of the political goals supported by feminism. This decreased support is demonstrated by decreased funding for women's programs (Gergin, 2011), and by not respecting treaty rights of Indigenous peoples on issues such as education and healthcare (Rennie, 2014). As a former Canadian conservative politician puts it, in the conservative worldview "social justice is achieved when an individual successfully moves from dependence to independence” (Solberg, 2009). In sum, conservative governments in Canada offer less support for social justice initiatives.

As with almost everything pertaining to social relations, social justice is a contested term rooted in ideology. Indeed, progressive notions of social justice promote social programs to help economically marginalized people and promote cultural pluralism through the help of the state (Orlowski, 2011). Progressives believe in the role of government to intervene in social and economic relations such that the suffering of marginalized groups along axes of race, ethnicity, class, gender, sexuality, ability, and age is mitigated. By contrast, conservative conceptions of social justice encourage acts of charity to help lessen suffering rather than state intervention (Anderson, 2011). In the next section, this broad generalization will be described in more nuanced terms of what is meant by conservative Christianity's relation to social justice. 
From a progressive perspective, teaching for social justice is to encourage students to "perceive social, political, and economic contradictions, and to take action against the oppressive elements of reality" (Freire, 1995, p. 17). Greene (1998) argues that to teach for social justice is to teach "for the recognition of social wrongs, of sufferings" (p. xlv). Many citizens would not agree that teaching for social justice is the proper role for teachers. Often these differing perspectives are the result of ideological differences. Sometimes these ideological differences around social justice are the result of one's faith.

\section{Progressive and Conservative Christianity: Exploring Social Justice Issues}

Christian responses to social justice in North America run along a continuum. According to theologian Ronald Sider (2008), "Christians embrace contradictory positions on almost every political issue” (p. 11). This is not a new development: For many centuries Christianity has been divided along ideological lines (Bass, 2009; Choquette, 2004). There is a long running debate within Christian circles about whether one should focus on living a life that ensures their entry into heaven, or whether it is best to devote one's life to social justice issues in order to lessen the suffering of others in the here and now (Bass, 2009; Blaikie, 2011; Sider, 2008). This binary can also be expressed as individualism versus the commons, or self-interest versus altruism. The extent to which a Christian focuses on social justice is paramount to understanding this debate.

Within Protestantism, fighting for social justice is most closely aligned with the Social Gospel tradition that posits progressive social reform rather than personal salvation is in the true spirit of Christianity (Blaikie, 2011). One noteworthy accomplishment within the American Social Gospel tradition is the American Civil Rights movement headed by Baptist preacher Martin Luther King Jr. that culminated with the Civil Rights Act of 1965. In Canada, the Baptist preacher Tommy Douglas led a successful struggle for a fully funded public healthcare system in the province of Saskatchewan that came to fruition in 1962. Progressive Catholicism in politics, especially in Latin American circles, is most often associated with Liberation Theology, a theological movement that emanated out of Latin America in the 1960s. It emphasized that the Gospels were meant to help liberate the downtrodden from poverty and oppression. Involving the Catholic faith into political and civic affairs was the strategy to end their suffering. Pope Francis, who grew up in Argentina, has long been influenced by Liberation Theology (Ivereigh, 2014).

As with the politics of most social groups, the ideology of Christians is situated across the political spectrum. An example of the contradictions within contemporary Christianity in the United States occurred in 2010 when a popular television show host on Fox News, Glenn Beck, told his listeners to leave any church that uses the words "social justice" (as cited in Wallis, 2011). A progressive Christian leader, Jim Wallis (2011), quickly responded to Beck’s declaration, writing, "The Bible is clear: from the Mosaic Law of Jubilee, to the Hebrew prophets, to Jesus Christ, social justice is an integral part of God's plan for humanity” (p.1). Indeed, it is this clear distinction around the two ideological positions around Christian conceptions of social justice that led me to undertake this study.

Caution must be exercised in assumptions about conservative Christians in Canada and their American counterparts. Christian theologians in Canada and the United States share similar theological interpretations of the Bible as well as moral concerns (Reimer, 2003; Stackhouse, 1993). It is important to note, however, that Canadian Christians are influenced by mainstream Canadian values and Canadian political culture in the same way that American Christians are 
affected by American values and politics. In other words, it is dangerous to apply generalizations and analysis of American Christian rhetoric to the Canadian context. For example, conservative evangelicals in Canada demonstrate much more tolerance than American evangelicals (Reimer, 2003). Rayside and Wilcox (2011) found that during the 1970s there was a dramatic increase in both countries for gay rights. "Public recognition of sexual minorities have been politically settled" in Canada (Rayside \& Wilcox, 2011, p. 5). All federal political parties, including the Conservative Party of Canada, have now accepted gay marriage. This is the not the case with most American conservative Christians, nor with the Republican Party (Sider, 2008).

To assume a common political ideology for Canadian Christians is a misguided endeavor. As an example of an issue addressed in this study, the President of the Evangelical Fellowship of Canada made the following claim about how best to address poverty: "Some evangelicals want a more interventionist state; others want smaller governments and more ownership by charities and individuals in addressing social needs" (Clemenger, 2004, p. 1). Moreover, the political ideology of Canadian Christians is fluid. Pollsters found that the Liberal Party of Canada at one time received more support from evangelicals than the other parties (Hutchinson, 2009). In recent years, however, more voters that are evangelical support the Conservative Party of Canada, often because of a perceived anti-evangelical attitude among Liberal leaders (Hutchinson, 2009).

Different ideological interpretations of the Bible pertain to the notion of human rights. Quite often, rights along both civil-political and social-economic axes collide. The progressive stance supports the following principles:

- The needs of the poor are above the wants of the wealthy;

- The freedom of the dominated over the liberty of the powerful; and

- The democratic participation of marginalized groups takes precedence over the exclusionary status quo.

In sum, the progressive Christian perspective on social justice measures a society by the manner in which the poor and marginalized are treated (Sider, 2008). This is not the conservative Christian perspective. How does this play out in American social studies classrooms?

\section{Christian Teaching of the Social Sciences in the United States}

Studies of Christian teachers in the United States indicate that conservative values are the norm rather than the exception in social studies and civic studies classrooms. Indeed, most studies indicate a general reluctance to deliberate multiple viewpoints, eschewing one of the cornerstones of sound democratic education (Sikkink, 2010). According to the research, conservative Christian teachers do not address controversial issues. If they do, progressive perspectives are absent, using omission as a hegemonic strategy (Kunzman, 2006a, 2006b). There are exceptions, of course. For example, Whitlock (2007, 2010) has written about the process of reconciling her Christian church-going past with being a lesbian teacher and teacher educator, and of her difficulties in teaching preservice teachers about queer politics.

In a study of elementary social studies methods courses, James (2010) found that many conservative Christian preservice teachers in her classes have difficulty embracing certain democratic ideals, particularly those that require deliberation and participation. "Theologically certain” students, according to James, often refuse to participate in class discussions or ponder opinions that differ from their own. This mirrors current trends in American society. Moreover, 
James (2010) contends that some conservative Christian preservice teachers "resist the very notion that democracy constitutes a worthy end of public education at all” (p. 619). Clearly, such people are not well-suited to teach social studies in schools. To eschew democratic education is to step away from supporting the public good and the commons in favor of the individual and private interest. James (2010) makes the important point, however, that some Christian preservice teachers demonstrate "mature religiosity," or a willingness to participate in dialogue with people who do not necessarily share the same viewpoints on social and economic matters (p. 631).

Kunzman (2006a) examined a civics education curriculum intended for "the million-plus and growing number of conservative Christian homeschooled students in the United States” (p. 164). The curriculum, called Generation Joshua, included pedagogy on how to ban gay marriage, on discouraging women from taking leadership positions, and on supporting a Christian United States of America. Kunzman (2006a) found that in general, "civic education for conservative religious homeschoolers ... is little better than no civic knowledge and skills at all” (pp. 165166). This finding led him to conclude that teachers and teacher educators need to cultivate in students skills to discern the difference between reasonable disagreement and irrational, closed positions based on faith. The latter position is similar to what James (2010) refers to as "theological certainty." Kunzman (2006a) furthers this line of reasoning by stating that teacher education should engage in a "sort of societal construction project" focused on civic deliberation skills that are necessary to help decide "how to live together in society" (p. 168). Social studies and civics, according to Kunzman, must hold “mutual goodwill” as a major objective.

Kunzman (2006b) considers religiously informed citizenship to be a major challenge in the struggle to strengthen civil society. In order to bring Christian conservative students into class discussions of controversial issues, he implores teachers to eschew any pretense of neutrality and help students "thoughtfully and respectfully grapple with the good as it is envisioned by a range of religious and other ethical perspectives” (p. 4). In short, teachers and teacher educators must model and encourage ethical dialogue among students. This involves "cultivating empathetic understanding of unfamiliar ethical perspectives," followed by "civic deliberation in light of this understanding” (p. 6).

This study examines how Christian principles of social justice influence the ways in which Christian teachers think about Indigenous peoples, multiculturalism, poverty, social programs, unions, and the rights of gay and lesbian people. One must be cautious in making assumptions, of course, but one could assume that their thinking influenced how they teach about these important topics.

\section{Methodology}

\section{Recruiting the Participants}

The participants were recruited through a mail-out invitation my research assistant sent to the 48 active secondary social studies teachers who belonged to the Saskatchewan Social Science Teachers Association. The mail-out contained a letter inviting participation and a pamphlet briefly highlighting the study. Beneath the University logo, the pamphlet cover had in large bold words: Christianity, Social Studies, \& Social Justice. There were two requirements for the potential participants that were clearly stated in both the letter of invitation and the pamphlet: First, they must self-identify as a Christian; and second, they must have at least three years of 
experience teaching social studies at the high school level. I wanted high school teachers because many of the topics I was inquiring about, such as labor unions and taxes, are only included in the high school curriculum. The mail-out strategy worked-ten teachers who met the requirements contacted me. Subsequent correspondence led to their participation.

\section{Data Collection}

This was a qualitative study and one-on-one, face-to-face interviewing was the only source of data collection used (Conrad \& Schober, 2008). It would have been valuable to triangulate what the teachers claimed in the interviews by actually observing them teach. Yet, this would have been impractical-the teachers taught in schools across the entire province, and the variety of topics would have been covered at varied times during the school year by each teacher. How closely do the teachers' descriptions of how they think and teach about social justice issues match what they do and say in the classroom? I assumed that the teachers tried their best to describe their thoughts and actions around teaching the issues about which I had asked. The educational literature in the United States consistently demonstrates that teachers strive to integrate their personal and professional identities (Sikkink, 2010).

For this study, I developed a set of semi-structured, open-ended questions that enabled me to gain insight into the teachers' thoughts about social justice issues (see Appendix A). In late 2013 and through 2014, I conducted one-on-one interviews with all 10 teachers in settings of their choice in both urban and rural locations across Saskatchewan. Each interview was between 60 and 90 minutes.

In terms of demographics, the participants were equally divided between Catholics and Protestants. Four of them taught primarily in public schools, while three taught in Christian schools and the other three taught in the Catholic school system. ${ }^{2}$ There were six men and four women, six taught in urban schools while four taught in rural Saskatchewan, and all of them had taught for at least five years (see Table 1). All 10 teacher participants were White, and all selfidentified as practicing Christians; all claimed to attend either Catholic Mass or Protestant Church services on most Sundays. The data analysis determined that most participants shared certain values about society, as well.

Table 1: Participating Teachers Demographics*

\begin{tabular}{|c|c|c|c|c|c|}
\hline Name & Gender & $\begin{array}{c}\text { Catholic or } \\
\text { Protestant }\end{array}$ & Type Of School & $\begin{array}{c}\text { Urban or } \\
\text { Rural }\end{array}$ & $\begin{array}{c}\text { Number of Years } \\
\text { Teaching }\end{array}$ \\
\hline Walter & Male & Catholic & Public & Urban & 5 \\
\hline Darlene & Female & Catholic & Catholic & Urban & 21 \\
\hline Steve & Male & Protestant & Public & Rural & 15 \\
\hline Barbara & Female & Protestant & $\begin{array}{c}\text { Christian } \\
\text { (Public) }\end{array}$ & Urban & 5 \\
\hline Neil & Male & Protestant & $\begin{array}{c}\text { Christian } \\
\text { (Private) }\end{array}$ & Rural & 5 \\
\hline Cathy & Female & Protestant & $\begin{array}{c}\text { Christian } \\
\text { (Public) }\end{array}$ & Urban & 14 \\
\hline Wendy & Female & Protestant & Public & Rural & 6 \\
\hline Tom & Male & Catholic & Catholic & Urban & 12 \\
\hline
\end{tabular}




\begin{tabular}{|c|c|c|c|c|c|}
\hline Edward & Male & Catholic & Catholic/Public & Rural & 6 \\
\hline Kevin & Male & Catholic & Catholic & Urban & 28 \\
\hline
\end{tabular}

*Notes: Teachers are listed in chronological order of the actual interviews. Pseudonyms are used for all participants.

\section{Data Analysis}

There was only one data source for this study, namely, the transcripts for the 10 interviews. Coding of the transcripts was accomplished using an inductive approach. In other words, particular codes were assigned to text segments, which often turned into major themes. The codes were examined for inconsistencies, commonalities, assumptions, potential themes, connections to the literature, and given the research question, statements that indicated political ideology. The process was also reiterative, meaning that I repeated the process of analyzing the transcripts several times. This contributed to the rigour of the analysis (Creswell, 2012). The interview questions were designed to elicit discourses that indicated ideological perspectives on various social and economic issues (see Appendix A). The discussion in the Literature Review described the binary used. Perspectives were considered progressive on social issues if they supported minority rights and conservative if they did not. Progressive perspectives on economic issues were indicated for support of unions or for using tax dollars to strengthen the social welfare state. By corollary, if a participant expressed support for tax cuts or disdain for unions, they were categorized as conservative on that particular issue.

This study is an example of descriptive explanatory - themes and patterns emerged from analyzing the transcripts that helped explain the participants' beliefs and values. The responses by the teacher participants were rich and personal, and indicated the meaning each gave to various social justice initiatives based on their Christian faith. The analytic framework incorporated the binary of progressive versus conservative Christian positions on various issues as outlined in the Literature Review. The human condition is very complex, of course, and an individual would sometimes express conservative thoughts on some issues and progressive stances on others. This corresponds to many secular teachers as well as to the general public (Orlowski, 2011), and is addressed in the Discussion section.

\section{Findings}

In order to present the findings in a coherent manner, I will begin with discussions about the teachers' thoughts on two general topics: Teaching Social Studies, and Teaching for Social Justice. After analyzing the teachers' thoughts about teaching for social justice in general, subsections will follow on specific topics that include race, class, gender, and sexuality issues. Pseudonyms were used for all 10 participants throughout the entire paper. A discussion of the findings will follow this section.

\section{Right, Responsibilities, and Engaged Citizenship in Social Studies Teaching}

Three of the interview questions pertained to the main tenets of social studies education (see Appendix A, Questions 3, 4, and 8.) When asked what is the purpose of social studies, eight of the 10 participants said it was to help develop critically thinking and engaged citizens. Most said variations of the theme put succinctly by participant Wendy when she said that social studies is about "morals and ethics." Yet, the morals espoused by almost all of the participants in 
their teaching were not very different from what progressive secular social studies teachers claim (see Orlowski, 2011). The following quote by Walter encapsulates the dominant view:

I think what should be part of any social studies program is to teach about the oppression faced by any group in our society like gays and lesbians, First Nations ... When I teach about the exploitation of workers during the Industrial Revolution in History 10, I link it to the same sorts of things that happen to workers today.

For Walter and most of the other participants, the focus of social studies should be a type of antioppression education.

Neil, a veteran teacher of 14 years who was also a graduate student at a local university, went much further with his reply to the question about the purpose of social studies:

Neil: I think it's really important to distinguish my sense of what social studies could be versus the purpose I think it serves in society ... When I read curriculum documents I hear very staunchly a dominant sense of our province and our relationships kind of dragged kicking and screaming to anti-racist or progressive notions about what social studies might be about. I think social studies and history is where the norm is made normal, where it's normalized.

Paul: Are you suggesting that the result of social studies and history is often to entrench hegemonic norms?

Neil: Absolutely. This idea of reading the word and reading the world. I want to imagine a social studies where the kinds of reading of the word that we do gives possibilities of reading the world differently ... There is the potential within social studies to question, to deconstruct, and maybe offer a different way of being through how we teach social studies.

Neil clearly believed that social studies could be so much more progressive than it currently is. He said repeatedly throughout the interview that he taught social studies to deconstruct White racist attitudes toward Indigenous peoples. It is clear that Neil understood that there are multiple interpretations about the purpose of social studies, much like his understanding that there are different interpretations of the Bible itself. This stance is an example of what James (2010) and others call mature religiosity.

The fourth question pertains to the idea that social studies should have a focus on the duties and responsibilities of being a citizen in a democracy. Christian influences permeated the responses of the majority of participants to this question. The following excerpts from two teachers demonstrate the influence of their Catholic faith on their views of citizenship:

Edward: Obeying authority just for the sake of it is definitely not the goal of what I mean to be a good citizen. Maybe surprising to some, [but] from a Catholic perspective just to obey authority has never been the goal. Teachers should have an active role to develop participation. We should help develop certain qualities of leadership in our students.

Kevin: Our main focus should be preparing students to participate in democratic society, to become citizens in a democracy. We have to allow people to have varying viewpoints ... Students will participate in all kinds of arguments on all kinds of issues. Even in our [Catholic] school, a majority of students feel that people should have access to pro-choice 
[on abortion], and some kids will cringe. I'll always say, "This is a democracy and we become richer by debating. You will learn from it. You will become a better person by listening to people that disagree with you. That's what I think we should be doing in Social Studies.”

The notion that an informed and active citizenry with the ability to understand multiple perspectives on complex social issues, as described by Kevin, is a progressive understanding of social studies. His response is very much in keeping with the goals of a liberal democracy. Kevin claims to encourage debate with his students as a way of becoming a "better person by listening to people that disagree with you." It would seem that Kevin in particular supports Kunzman's (2006b) notion of "grappling with the good" by deliberating a range of perspectives. Clearly, both teachers support the Deweyan notion that public education should be used to strengthen democracy. They claim to be cultivating in their students the ability to discern the difference between reasonable disagreement and an irrational close-mindedness based on faith (Kunzman, 2006a). In other words, they demonstrate mature religiosity rather than theological certainty (James, 2010).

A progressive view of democracy supports an inclusive political system best suited to increasing political, social, and economic rights for as many people as possible. The responses to the question around rights and responsibilities indicate near unanimity in their thinking (see Question 8): The group believed both are vitally important for students to understand. This question elicited some interesting answers, ones that took interesting twists and turns. Barbara, who teaches in a Christian school, offered one of these unexpected responses:

It's more important to teach about responsibilities because rights can be very dangerous. They lead to entitlement, and our students are already filled with a sense of entitlement and that's a real danger that I run into in my teaching. Because from our Christian perspective, God has given us this Earth to be keepers of it, so we have a responsibility to take care of it. We do not have the right to abuse it or take it for granted.

Barbara's interpretation of human rights is uncommon-she pointed to the manner in which a right can be taken to a negative extreme. Barbara was one of six participants who expressed unsolicited concerns about environmental degradation.

Wendy offered another interesting response to the question on rights and responsibilities:

If you have a right to live on this land that was traditionally the land of First Nations people, then you have a responsibility to learn about treaties and how they have affected you and how your family was able to get a house here on this land. [emphasis hers]

Many of the participants suggested that possessing rights means we have a responsibility to safeguard them for future citizens. Wendy's response, however, was positioned within the frame of Indigenous Land Treaties, a somewhat controversial topic in contemporary Saskatchewan (Tupper, 2012). She clearly supports the idea that residents have a responsibility to learn about treaties before they form an opinion of them, and before they assume land rights.

From the preceding discussion, it is obvious that the Christian participants in this study believe that democratic education should be part of social studies, unlike the Christian preservice teachers in James' (2010) study. This is one of many progressive positions that these Christian teachers held on important social issues. 


\section{Christian Teachers' Interpretations of Social Justice}

Six of the interview questions pertained to the broad topic of what it means to teach for social justice (Questions 9, 11, 12, 13, 14, and 15). The discussion begins by exploring the participants' thoughts on the actual phrase social justice. When asked what social justice means, and whether the role of the teacher is to teach for social justice, the responses would likely surprise many secular people: All 10 participants expressed strong support for the notion of teaching for social justice.

Barbara distanced herself from conceptions of social justice as acts of charity. She points to the transformative aspect of teaching for social justice inherent in Freire's conscientization (1970):

Social justice is more than just charity. You can't get out of my classes and not be changed forever. My own life has changed drastically after learning and teaching about these topics.

Barbara grew up in a conservative Baptist Church, one that she claims "is not known for social justice, it's just not part of their DNA.” Her life's journey has included lots of travel around the world. This experience has enabled her to see the world through a more progressive lens. She believes that the changes she has undergone are not transitory: "How I teach for social justice for the entire world, it isn't going to change. I've changed and will not go back to how I saw things before."

Many of the other participants demonstrated the influence of their Christian faith in how they think about teaching for social justice. Here are some short excerpts from the responses of Steve, Darlene, and Kevin:

Steve: Teaching for social justice is the Golden Rule.

Darlene: My definition of social justice is definitely grounded in my faith. Social justice is an important part of the Catholic Church's teachings. It is bringing a faith-based perspective to what's happening in the world, what is not right in the world. It's based on the concept of Jesus' preferential option for the poor.

Kevin: Social Justice is about the preferential treatment of the poor. I say to students that the biggest of our teachings is loving the poor. That's what Christ did. The measure of a society is how it treats its most vulnerable people.

These excerpts do not delineate between acts of charity and more leftist or state-interventionist considerations of what social justice means. One of the participants, however, made a clear distinction between the two ideological interpretations of social justice.

Neil: There were these Catholic guys like Paulo Freire and Ivan Illich who were saying some pretty important things in their progressive critiques of education. Their work, plus my background in the Old Testament, gave me a solid grounding in social justice ... There is a small $\mathrm{L}$ liberal version of social justice that actually is toothless. Teaching for social justice is really anti-oppression education.

Neil was not raised in the church, but became a Protestant as a young adult. He showed a degree of mature religiosity by being open to the radical teachings of Catholics such as Paulo Freire 
(1970, 1995) and Ivan Illich. Neil became aware of the work of Freire and Illich in a Teacher Education course called Christian Ethics that has a focus on social justice.

\section{Thinking About the Church, Indigeniety, and Other Cultures}

I asked the participants to share their views about Indigenous representation in the curriculum (see Question 11). All 10 participants were unanimous in their position: There is an acute need to teach about the unfair treatment of Indigenous peoples in Canada. Each teacher claimed to use the Treaty Kits that the Provincial Government sent to each school. All of the participants spoke of the need to teach about the racist residential schools policy and its legacy. The residential school policy, in which Indigenous children were taken from their families from ages six to 16, came into effect with the passing of the Indian Act in 1876. Its sordid history included the abuse of thousands of Indigenous children, and it is generally regarded as a particularly vile part of Canada's past (Battiste, 2013).

It is significant that four of the 10 participants want the role of the Church included in this topic. The responses of two Catholic teachers demonstrate a passion they possess for teaching about residential schools, including the role of the Catholic Church. White washing the ugly role the Church played in maintaining these schools was not part of their thinking.

Kevin: When we look back at First Contact, the Church felt that First Nations people were sub-human. At the time, this is what the Church believed. They were wrong, and I tell my students that they were wrong.

Edward: Aboriginal education and Aboriginal rights are something that I'm passionate about. As for dealing with Catholic Church issues, how could the Church be involved in the residential schools? Well, let's acknowledge that today no one thinks this was right ... Can you judge it today? Can you fault them? Yes. Could you reconcile it? Yes, we can reconcile it, we can hope, we can be stronger because of reconciling it.

It is clear that these teachers do not eschew pointing out grave mistakes made by the Catholic Church in its dealings with Indigenous people. It is also evident that at least some of today's Canadian Christian teachers are willing to acknowledge the role of the Church in the operations of the racist residential schools, and to criticize it for its complicity.

The Church was not the only institution that some of these teachers criticized. Two were particularly incensed when they learned that their own high school experience was a demonstration of how omission is used as a hegemonic strategy. Wendy, who lives and teaches in a predominantly First Nations community, explained how she felt when she first learned about the colonization of First Nations people.

Wendy: In my Bachelor of Education program, I had a few courses on First Nations history. I remember being angry, getting defensive as a White person, upset with the professor. And now I live here and work alongside First Nations people, and I'm learning more about the treaties and everything that has happened to First Nations people. So then I became angry at the government and got angry at my own high school education, thinking how could all this have been a secret my whole life? So I was just upset, completely upset. [emphasis hers] 
Wendy grew up thinking that what she was learning in school must be close to the truth, and felt outrage when years later she learned about Canada's colonial past. She vowed to rectify this omission in her own teaching, and claims she has done so. In fact, all 10 of the participants spoke of the need to teach about treaties and the importance for the Federal Government to finally honor the promises it made in the treaties that it signed in the 1870s.

As a result of the prosperous economy in recent years, most immigrants to Saskatchewan have come from non-European countries (Elliott, 2014, p. 21). It is interesting to note that only six of the 10 participants said they engage with multicultural education. Significantly, all six teach in urban settings, where most new immigrants reside. The position of the four teachers from rural communities is perhaps best summed up by the position of Edward:

Multicultural education. Does it equate to respect? I'm not sure, maybe it does. Learning about a culture without knowing someone from that culture, they're not as interested. I see that in the community where I live, you know, many people are racist against Aboriginal people. As I mentioned earlier, that's where my passion for teaching and social justice is.

It would appear that these teachers have become aware of the long history of colonialism and suffering experienced by the Indigenous peoples living on the territory now called Saskatchewan, and seem to be committed to teaching about it. The situation with the province's immigrants, however, has not made as significant an impact in their minds, especially among the rural participants. Given the relative novelty of residents from backgrounds other than Indigenous or European ancestry, this is perhaps at least partially understandable. Yet, at the same time, most students in rural Saskatchewan schools will come into contact with other racial minorities throughout their lives. In terms of teaching in a liberal democracy, multicultural education is an area in which these teachers appear to need professional development.

Two of the participants remarked on the disproportionate number of Indigenous people living in poverty. This race/class intersection is a serious issue in Saskatchewan. The study explored the participants' thoughts around economic issues in general.

\section{Christian Teachers on Helping the Poor and the Working Classes}

Two questions dealt with taxes, poverty, and unions (see Questions 13 and 14). Six of the 10 participants said that charity is not enough to lessen poverty, that government policy is the best way to help economically marginalized people. Darlene, Steve, and Edward succinctly explained their positions.

Darlene: I don't think charity is enough. I absolutely think that the government has to step in. The poverty problem is systemic. It is not something that can be solved by donating money or food, so it has to be fixed with changes to the system.

Steve: Canada is one of the wealthiest nations in the world. To have people living below the poverty line, no matter how one defines it, is a tragedy. I think absolutely the government has to respond. People living in substandard housing, people with addictions, people with mental and physical health issues, the government as my proxy needs to step in. I can't help them all, but the government can. 
Edward: I teach kids with a single mom working hard, raising three or four kids, and it's a struggle. Our governments have lost perspective on what the family does for society. People are not supported enough.

Responses such as these indicate very progressive stances toward poverty, tending toward a Keynesian model of government intervention in the economy. This stance positions them away from the conservative preference for self-reliance and small government. The binary of conservatism/progressivism fails to locate Edward's ideology, however. He expressed concern for the family, but by pointing to the need for single mothers to receive support, he did not invoke more familiar conservative discourses around family. In this regard, and throughout the entire interview, Edward, a Catholic teacher in rural Saskatchewan, demonstrated aspects of both conservatism and progressivism.

Most responses to the question about taxes and social welfare programs were quite progressive. For example, Kevin gave the following explanation about offering support for teen mothers at the Catholic high school where he teaches:

Kevin: If you're pro-life it doesn't mean that you're anti-abortion. That's what's good about our [Catholic] school—we have a program for teen moms. If we don't want them to abort that child, then darn it, we better support them and help them out!

Kevin proceeded to broach a topic that has puzzled me: Why do many Christians feel so strongly about the sanctity of life up until a child is born, yet support political parties opposed to social programs that help economically marginalized families?

Kevin: That's their attitude and it's the wrong attitude. When students in my classes say that the Conservatives are pro-life, I ask them how many abortions do they think the Conservatives have stopped with their tax cut policies? None! Not one!

Kevin's response suggests he eschews any pretense of political neutrality. Indeed, his position is an embrace of mature religiosity. Moreover, his reasoning suggests that economic policy affects the social lives of working-class people in important ways. Social programs such as the government-subsidized daycare policy of Quebec are opposed by Conservative parties across Canada. Yet these programs are designed to help struggling families with young children make ends meet by allowing a parent to get a job without paying exorbitant daycare fees. Kevin seemed to understand this disconnect within the conservative ideology. In this respect he demonstrated a progressive political consciousness.

Teacher neutrality was also absent when I asked the participants about labor issues, including whether they taught about unions. Only two of them took a decidedly clear anti-union position. Seven out of the 10 participants said that they teach about the contributions unions have made to society. Most discuss the rise of the trade union movement while teaching about the deplorable working conditions during the Industrial Revolution. Five of the teachers say that they use this topic to segue into teaching about the contemporary abhorrent practice of using sweatshop labor. Tom described how he used the Industrial Revolution to teach his students about workers' rights and the use of labor strikes.

Tom: Last year I was teaching about the Industrial Revolution in England and workers' rights and started to talk about why workers sometimes strike to have their voice heard. Well, right as this unit was just about finished the [province's] teachers went on strike 
here. I saw that the students were hearing what their parents were saying about it, and what the media was saying about it. And we as teachers were told to not talk about it very much. Well, why not? The kids didn't know anything about why we were striking. Mom and Dad don't know either if they're not using a critical lens to view what's being told in the media.

Tom is obviously overt about his pro-union stance. This surprised me to some extent because other studies I have been involved with demonstrated the reluctance of many secular teachers to show their support for unions in the classroom (See Orlowski, 2011). Tom was not the only one taking a supportive stance on unions, however. Kevin explained:

I have a poster on my classroom door of a little boy saying, "If it wasn't for unions, I'd already be working." Our students need to understand what unions have done for us in Canada and elsewhere. [emphasis added]

This support for unions immediately positions Kevin as a progressive on this issue. By contrast, two of the participants expressed variations of an anti-union perspective. Almost all of the participants, however, expressed gratitude for being part of the Saskatchewan Teachers Federation. This suggests that the majority have progressive politics toward labor issues, including unions.

Taken collectively, the group of participants was very much in favor of a strong social welfare state. It is noteworthy that five of the participants said that they refer to the Christian phrase "Preferential Option for the Poor" in their classroom teaching. ${ }^{3}$ In this study, the Christian teachers did not seem to be influenced by right wing economic discourses that favor individual responsibility and a smaller social welfare state.

\section{Weighing in on the Rights of Women and LGBTQ People}

The question on the Canadian Charter of Rights and Freedoms, legislation that came into being in 1982, included probes around feminism and sexuality (see Question 15). Eight of the 10 teachers claimed to be supportive of teaching for a more egalitarian society in terms of gender. Three of them said they actively teach about the rights of women when they cover the Charter in History 30. One of the two dissenting voices, Edward, expressed resistance to a particular strand of feminism in particular, but also to feminism in general:

You've got to bring out the spectrum of feminism because there's a wide variety, including a very extreme radical feminism ... Has feminism helped the situation for women? No, I don't think so. The way women are now being treated in society, the gross amount of single mothers, the lack of support for them, the way they are perceived in the media, is that better off? Are we any better off than how it was 50 years ago? Not really.

Many of Edward's comments around gender seemed to emanate from good intentions. (Recall his lament for the lack of government support for single mothers.) Yet, this statement clearly emanates from a conservative perspective that supports patriarchy. He has not considered the experiences of most women who feel that their own mothers and especially their grandmothers led much tougher lives than they now lead. Edward's remark linking feminism to how they are perceived in the media misses how capitalism and patriarchy have combined to create the objectification and sexualized representation of women in the media. Overall, Edward's view exemplified a typical conservative perspective toward gender. 
Edward was also the only participant to oppose the notion of gay rights. His reasoning was strictly because of his interpretation of biblical passages. He exhibited theological certainty on issues of sexuality and gender. This suggests he is not interested in teaching students the mutual goodwill (Kunzman, 2006a) or cultivating empathetic understanding (Kunzman, 2006b). Not only did he oppose gay rights, Edward was also staunchly opposed to sex education being taught in the schools. He incorrectly claimed that such programs actually increase the number of teen pregnancies and sexually transmitted diseases. Edward said that he tells his students this when they ask about sex education. This was one of the few examples in the entire study that secular concern about the content taught in religious schools goes against what a liberal democracy stands for (Feinberg, 2006). Edward was a clear anomaly in the study around issues of gender and sexuality.

Nine of the participants were supportive of gay rights, and eight of them claimed to actively teach about it. I asked Walter how his pro-gay rights position is reconciled with the official anti-gay rights stance of the Catholic Church.

Walter: I self-identify as a Catholic, but I always describe myself as a critical Catholic. I think that learning catechism is important but I also live in the world today. I don't subscribe to the idea that the Bible was written through divine influence. It's a human document and must be interpreted in a historical perspective ... If you're going to criticize gay marriage, then I'm going to ask if you think we should stone adulterers caught in the act, or ask why you're wearing poly-cotton clothes.

Walter mentioned an issue that I have heard many secular progressives state: the notion of cherry-picking biblical verses that support a particular political position and ignoring ones that oppose it. He was not concerned that the Bible is filled with verses diametrically opposed to each other on various positions. As Walter said, "It's all about interpretation.”

Walter was one of seven participants who suggested that they veer away from Biblical interpretations that do not conform to the values of mainstream contemporary society in Canada. This was an unexpected theme that emerged from the data. It is also of great importance in terms of teaching for mutual goodwill and how best to live together in an increasingly diverse society (Kunzman, 2006a).

As an example of this, Darlene took a very pro-gay rights position and expressed both gratitude and pride that the Catholic School Division where she works "has done some serious anti-homophobic professional development" with its teachers. "We need to welcome everyone," she said. Darlene's position was very much the majority view among the participants. On the issue of teaching about gay rights, all 10 claimed to drop any pretense of neutrality in the classroom, something Kunzman (2006b) stresses is important if students are to learn how to live together in society. Yet, the closed-minded views of Edward around gender and sexuality are problematic and would inevitably prove to be an obstacle in teaching for mutual goodwill.

Seven of the 10 participants said that they actively encourage their students to voice their opinions on controversial topics in their classrooms. This is a foundational principle of schooling in a liberal democracy. Cathy, who teaches in a Christian school, explained her pedagogical strategy: 
I play devil's advocate quite a bit because I want the students to figure out what their own opinion is ... If your opinion is in opposition to what our faith says, you better be able to back it up-if you can, that's fine. Gay rights is one of those topics.

Cathy's explanation answers one of the study's research questions, namely, how do Christian social studies teachers claim that Christian interpretations of social justice influences their teaching of values and perspectives on political issues? Cathy's response, as well as responses by most of the others, indicates support for this important educational objective of schooling in a liberal democracy.

\section{Summary}

Overall, the majority of the participants held progressive views on every one of the potentially controversial issues we discussed in the interviews (see Table 2). Looking at the binaries of Protestant-Catholic, female-male, and urban-rural, only geography provided any significant difference in the expressed views of the teachers. Although most responses tended toward the ideologically progressive, all 10 negative positions out of the 60 in total were from teachers working in rural communities.

The 10 teachers were unanimous in their views about the need to teach Indigenous perspectives on Canadian history, including the treaties. Four participants called for teachers to discuss the role of the Christian churches in the horrific experiences many First Nations children had in residential schools. There was some discrepancy in the teachers' thinking around multicultural education. All four teachers based in rural communities did not consider this an important topic in their social studies courses. By comparison, all six teachers based in urban settings considered it an important topic. This discrepancy is likely influenced by differing cultural compositions of the cities compared to rural Saskatchewan.

There was complete unanimity among the participants in their thinking about issues related to poverty and social programs; although the discussions did not delve into the pedagogy they used to teach these topics. There was less agreement, however, on the need to teach students about the trade union movement's contributions to civil society: three of the four rural teachers expressed dissenting views about teaching labor history. Although there were two dissenting voices on teaching feminist perspectives and one on gay rights, the majority of participants were in favor of an egalitarian society based on gender and sexuality.

Table 2: Teachers’ Views on Teaching About Race, Class, Gender, and Sexuality From a Progressive Standpoint

\begin{tabular}{|c|c|c|c|c|c|}
\hline Name & Sex & Religion/Location & $\begin{array}{c}\text { Race Focus } \\
\text { IndigenousEd/ } \\
\text { Multicultural } \\
\text { Ed }\end{array}$ & $\begin{array}{c}\text { Class Focus } \\
\text { SocialPrograms } \\
\text { /LaborUnions }\end{array}$ & $\begin{array}{c}\text { Gender/ } \\
\text { Sexuality } \\
\text { Focus }\end{array}$ \\
\hline Walter & Male & Catholic/Urban & Yes/Yes & Yes/Yes & Yes/Yes \\
\hline Darlene & Female & Catholic/Urban & Yes/Yes & Yes/Yes & Yes/Yes \\
\hline Steve & Male & Protestant/Rural & Yes/No & Yes/Yes & Yes/Yes \\
\hline
\end{tabular}




\begin{tabular}{|c|c|c|c|c|c|}
\hline Barbara & Female & Protestant/Urban & Yes/Yes & Yes/Yes & Yes/Yes \\
\hline Neil & Male & Protestant/Rural & Yes/No & Yes/No & Yes/Yes \\
\hline Cathy & Female & Protestant/Urban & Yes/Yes & Yes/Yes & Yes/Yes \\
\hline Wendy & Female & Protestant/Rural & Yes/No & Yes/No & No/Yes \\
\hline Tom & Male & Catholic/Urban & Yes/Yes & Yes/Yes & Yes/Yes \\
\hline Edward & Male & Catholic/Rural & Yes/No & Yes/No & No/No \\
\hline Kevin & Male & Catholic/Urban & Yes/Yes & Yes/Yes & Yes/Yes \\
\hline
\end{tabular}

To some extent the discrepancies in the responses between the urban and rural teachers makes sense. In Saskatchewan, as in most regions of Canada and the United States, rural communities tend to be more conservative. This comes out in voting patterns, of course, and it is corroborated by the study's findings. Teachers may find themselves in trouble with school administrators or parents if they teach certain perspectives that do not correspond to community values. Yet, overall, it is interesting to note that all of the teachers in the rural communities held progressive perspectives on Indigenous and working-class issues. All six urban teachers expressed progressive views on every issue about which I asked. The four rural teachers expressed a combination of progressive and conservative responses, depending on the issue.

\section{Discussion and Significance of the Study}

The findings in this study challenge and complicate studies of Christian social studies teachers in the United States. On each political issue explored with the 10 Saskatchewan teachers, the majority voiced progressive stances. An important question that begs to be asked is this: Why are the Christian teachers in this study so much more progressive than in the American studies? I argue that religious people are influenced by mainstream political values just like everyone else, and this would also hold for religious teachers, of course. This suggests that mainstream Canadian society might be considered more progressive than mainstream American society. Support for Canada's universal healthcare system is one indicator. Certainly, this would also be the situation around gay marriage and the rights of LGBQT people-Conservative governments across Canada have accepted these progressive stances while Republican governments have not. (This is not to suggest, however, that homophobic attitudes are near non-existent in Canada.)

The different ideological stances on political matters between the American and Canadian teachers may possibly also be a result of differences in teacher education programs in the two countries. In Saskatchewan, there are two universities with teacher education programs. All preservice teachers are required to take courses that address Treaty Education. Moreover, at the University of Saskatchewan, all students planning to teach in the Catholic school system are required to take a course called Christian Ethics. Some Protestant preservice teachers take this course, as well. The focus is on discussion of controversial issues from a Christian perspective. At the University of Regina (in Saskatchewan), there is a course for preservice teachers called Moral Education. Many also access a Catholic Studies elective course called Theory and Practice of Catholic Education through a local university college affiliated with the University of Regina. 
The mandate of this Catholic university college is to offer a liberal arts education to the Catholic students of southern Saskatchewan. These teacher education courses in Treaty Education and Christian Ethics may provide a major reason why the Saskatchewan Christian social studies teachers in the study were decidedly more progressive than those in the American studies. For example, Neil expressed support "to deconstruct [hegemonic norms] and offer a different way of being through how we teach social studies.” He cited progressive Catholic educators Paulo Freire and Ivan Illich that he came across in the Christian Ethics course in his teacher education program as instrumental in his own political awakening.

The findings in this study, however, point to areas in which teacher education programs in Saskatchewan could also improve. All six participants teaching in urban schools voiced support for progressive positions on every issue discussed-but this was not the case with the four rural-based participants. For example, as mentioned in the Summary section, the six urbanbased teachers considered multicultural education an important component of social studies while all four rural-based teachers did not. Yet, students in rural schools may find themselves working alongside people from other cultures once they leave school. This will also be the likely scenario around diverse sexualities. Perhaps courses can highlight or even model best pedagogical practices to address controversial issues in communities with entrenched oppressive attitudes toward the Other.

The current Christian Ethics and Moral Education courses in Saskatchewan's teacher education programs should also incorporate content that illuminates the Church's role in the dark side of Canadian history. Four teachers expressed unsolicited opinions that the Church's role in subjugating First Nations children to horrific abuse in the century-long residential school policy should be taught. Indeed, these four teachers claimed to teach about this sordid history so that the Church "can be stronger from reconciling” this experience, as Edward put it. These teacher education courses in ethics should demonstrate to preservice teachers how to pedagogically approach controversial issues such as the Church's historical role in oppressing Indigenous people, women, and LGBTQ people.

A few other points revealed in this study as they relate to the Literature Review are worth mentioning. Seven of the 10 participants claimed to actively encourage discussions around controversial issues with their students. Each one of them claimed to promote a progressive social justice stance on these issues. Cathy, a teacher in a Christian school, claimed to play the "devil's advocate" with her students on issues such as gay rights: "If your opinion is in opposition to what our faith says, you better be able to back it up. If you can, that's fine.” This stance is completely in line with teaching in a liberal democracy (Feinberg, 2006). For the most part, these Christian teachers demonstrated a "mature religiosity" (James, 2010) in which they appeared to be open to different and more progressive perspectives than the typical conservative stance. Indeed, seven of them stated that they do not accept biblical interpretations that work to oppress marginalized peoples in contemporary society.

Kunzman (2006a) calls for teachers to design pedagogy that asks, "How do we live together in society?” Although my study did not observe classroom teaching, each teacher offered thoughts that support Kunzman's suggestion. The fact that all 10 claimed to feel strongly about the need to teach about the government's unfulfilled promises toward First Nations peoples is a testament to that. Further, all 10 discussed the need to teach about poverty and social programs from a progressive standpoint. Kunzman (2006b) argues that teachers should drop any 
pretense of neutrality and provide students with a plethora of perspectives. All 10 interviews were replete with examples of teachers claiming to offer their stances on political topics. Indeed, one striking example was when Kevin, the most senior participant, claimed he would help his Catholic students understand that the Conservative Government's penchant for tax cuts and weakened social programs works against the objective of decreasing the number of abortions.

One flaw in this study that may also account for ideological differences between the participant perspectives in this study and the cited American ones was likely a result of the recruitment process I used. The initial mail-out specifically asked for Christian social studies teachers who wanted to discuss social justice issues. The inclusion of the term social justice may have discouraged more conservative teachers from participating. There are definitely Christian teachers in Saskatchewan who adhere to the conservative ideology. This study, however, is evidence that some Christian teachers in the province are progressive on social and economic issues. It is clear that Christian teachers in Saskatchewan schools cannot be considered a monolithic group on political matters. This in itself is an important finding in terms of responding to secular critiques of the influence of Christianity in Saskatchewan schools today.

\section{Conclusions}

This is the only study I am aware of that asks how high school, Christian, social studies teachers think about social justice and various social and economic issues. I expect that readers will have a better understanding of why the article is entitled "The Light to the Left." The vast majority of the political stances were progressive; very few emanated out of conservatism.

The first of the two research questions asked: How do practicing teachers of social studies who adhere to the Christian faith understand the term social justice? Although many of the 10 participants mentioned Christian tenets (such as the Preferential Option for the Poor), their positions were not very different from secular progressive teachers. This was especially the case with the six urban teachers. The second research question asked: How do they claim that this understanding of social justice influences their teaching of values and perspectives on political issues? Again, in almost every case the participants claimed to teach from a progressive standpoint on the issues explored in this study. If we make the reasonable assumption that social studies pedagogy is influenced by one's personal perspectives, however, then it is safe to say that these teachers educate their students to become more tolerant toward the marginalized Other.

It would be unwise to make too many wide sweeping generalizations about these findings. After all, 10 social studies teachers in one Canadian province is too small a sample set to provide significant reliability or verisimilitude. Yet, the findings appear to complicate and challenge common secular perceptions of Christians in general, let alone Christian social studies teachers. This study is important for that reason, but also because the findings suggest ideas for teacher education programs that focus on how we can live together more harmoniously despite differences. Social studies is a vitally important course for this endeavour, regardless of whether the teacher is religious or secular.

\footnotetext{
Endnotes

${ }^{1}$ Indigenous is an inclusive term that refers to First Nations, Métis and Inuit peoples. Aboriginal is a Eurocentric term that also refers to the same three groups. In this paper, I use Indigenous, but some of the teachers' quotes include the term Aboriginal.
} 
${ }^{2}$ In Saskatchewan, all Catholic schools are funded from tax dollars to the same extent as public schools. The Christian schools represented in this study are also publicly funded and are administered through public school divisions.

${ }^{3}$ The Preferential Option for the Poor is a relatively new Christian phrase. Its first use in a Church document is from a 1968 meeting of the Conference of Latin American Bishops held in Medellin, Columbia. It refers to the importance of Christian service to the (economically) marginalized in society. Pope Francis has mentioned it in several of his recent speeches.

\section{References}

Anderson, R. (2011, November 7). Conservatives and social justice. Public Discourse. Retrieved from http://www.thepublicdiscourse.com/2011/11/4244/

Bass, D. B. (2009). A people's history of Christianity: The other side of the story. New York, NY: HarperCollins.

Battiste, M. (2013). Decolonizing education: Nourishing the learning spirit. Saskatoon, SK: Purich.

Blaikie, B. (2011). The Blaikie report: An insider's look at faith and politics. Toronto, ON: United Church Publishing House.

Chancey, M. (2007). A textbook example of the Christian Right: The National Council on Bible Curriculum in Public Schools.” Journal of the American Academy of Religion, 75(3), 554-581.

Choquette, R. (2004). Canada's religions. Ottawa, ON: University of Ottawa Press.

Clemenger, B. (2004, May/June). How and Why Evangelicals Vote. Faith Today. Retrieved from http://www.evangelicalfellowship.ca/page.aspx?pid=1753

Conrad, F., \& Schober, M. (2008). New frontiers in standardized survey interviewing. In S. Hesse-Biber \& P. Leavy, (Eds.), Handbook of emergent methods, (pp. 173-188). New York, NY: Guilford.

Creswell, J. (2012). Educational research: Planning, conducting, and evaluating quantitative and qualitative research ( $4^{\text {th }}$ ed.). Columbus, $\mathrm{OH}$ : Merill Prentice Hall.

Dewey, J. (1916). Democracy and education. New York, NY: MacMillan.

Douglas, F., \& Gingrich, P. (2009, November). Child and family poverty: Saskatchewan report. Social Policy Research Unit, University of Regina. Retrieved from http://www.campaign2000.ca/reportCards/provincial/Saskatchewan/2009PovertyReportC ard.pdf

Elliott, D. (2014). Demographic trends in Saskatchewan. Sask Trends Monitor. Retrieved from http://www.saskculture.ca/content/generic_atoms/titlefilecaptionfiles/14.05.26.Diversity.Doug_Elliot.pdf

Feinberg, W. (2006). For goodness sake: Religious schools and education for democratic citizenry. New York, NY: Routledge. 
Feinberg,W., \& Layton, R. (2013). Teaching Bible in public high schools: Toward a conception of educational legitimacy. American Educational Research Journal, 50(6), 1279-1307. doi: 10.3102/0002831213502517

Freire, P. (1970). Pedagogy of the oppressed. New York, NY: Continuum.

Freire, P. (1995). Teachers as cultural workers: Letters to those who dare to teach. New York, NY: Perseus Books.

Gergin, M. (2011, April 6). Silencing dissent: The Conservative record. Canadian Centre for Policy Alternatives. Retrieved from https://www.policyalternatives.ca/publications/commentary/silencing-dissentconservative-record

Government of Saskatchewan (2011). Saskatchewan Statistical Immigration Report: 2002-2011. Retrieved from http://www.economy.gov.sk.ca/immigration/sk-immigration-statisticalreport-2011

Greene, M. (1998). Introduction: Teaching for social justice. In W. Ayers, J. A. Hunt, \& T. Quinn (Eds.), Teaching for social justice (pp. xxvii-xlvi). New York, NY: Teachers College Press.

Haynes, C. (2011). Getting religion right in public schools. Phi Delta Kappan, 93(4), 8-14.

Howe, E. (2011). Bridging the Aboriginal education gap in Saskatchewan. Saskatoon, SK: Gabriel Dumont Institute.

Hutchinson, D. (2009, August). Evangelical voting trends by region, 1996-2008. Church \& Faith Trends, 2(3). Retrieved from http://files.efccanada.net/min/rc/cft/V02I03/Evangelical_Voting_Trends_1996-2008.pdf

Ivereigh, A. (2014). The great reformer: Francis and the making of a radical pope. New York: NY: Harry Holt.

James, J. H. (2010). “Democracy is the devil's snare”: Theological certainty in teacher education. Theory \& Research in Social Education, 38, 618-639.

Journell, W. (2011). Teachers' controversial issue decisions related to race, gender, and religion during the 2008 Presidential Election. Theory \& Research in Social Education, 39, 348392.

Kunzman, R. (2006a). The civic (and pedagogical) virtue of recognizing reasonable disagreement. Theory \& Research in Social Education, 34, 162-182.

Kunzman, R. (2006b). Grappling with the good: Talking about religion and morality in public schools. Albany, NY: State University of New York Press.

Levy, J. (1975). Cesar Chavez: Autobiography of La Causa. New York, NY: W. W. Norton \& Company.

McGrane, D. (Ed.). (2011). New directions in Saskatchewan public policy. Regina, SK: Canadian Plains Research Centre Press. 
Orlowski, P. (2015). Neoliberalism, its effects on Saskatchewan, and a teacher educator's response. Alternate Routes: A Journal of Critical Social Research, 26(1), 223-250.

Orlowski, P. (2014). Social studies \& civil society: Making the case to take on neoliberalism, in education, 20(1), 3-24.

Orlowski, P. (2011). Teaching about hegemony: Race, class \& democracy in the 21st century. New York, NY: Springer.

Rayside, D., \& Wilcox, C. (2011). Faith, politics, and sexual diversity in Canada and the United States. Vancouver, BC: UBC Press.

Reimer, S. (2003). Evangelicals and the continental divide: The conservative Protestant subculture in Canada and the United States. Montreal, PQ: McGill-Queen's University Press.

Rennie, S. (2014, April 28). First Nations leaders call on Conservatives to scrap Aboriginal education bill, hint at blockades. National Post. Retrieved from http://news.nationalpost.com/2014/04/28/first-nations-leaders-call-on-conservatives-toscrap-aboriginal-education-bill-hint-at-blockades/

Richards, J. (2008). A disastrous gap: How high schools have failed Canada's Aboriginal students. Toronto, ON: C. D. Howe Institute.

Sadovnik, A., Cookson, P., \& Semel, S. (2013). Exploring education: An introduction to the foundations of education, $4^{\text {th }}$ ed. New York, NY: Routledge.

Schmidt, T. (2007). Journeys to the heart of Catholicism. Hamilton, ON: Seraphim Editions.

Schweber, S. (2006). “Breaking down barriers” or "building strong Christians”: Two treatments of Holocaust history. Theory \& Research in Social Education, 34, 9-33.

Sider, R. (2008). The scandal of evangelical politics: Why are Christians missing the chance to really change the world? Grand Rapids, MI: Baker Books.

Sikkink, D. (2010). Do religious school teachers take their faith to work? Research evidence from the United States. Theo Web: Academic Journal of Religious Education, 9(1), 160179. Retrieved from http://www.theo-web.de/zeitschrift/ausgabe-2010-01/12.pdf

Solberg, M. (2009, November 26). The conservative vision of social justice. C2C Journal. Retrieved from http://c2cjournal.ca/2009/11/the-conservative-vision-of-social-justice/

Stackhouse, J. (1993). Canadian evangelism in the twentieth century: An introduction to its character. Toronto, ON: University of Toronto Press.

Tupper, J. (2012). Treaty education for ethically engaged citizenship: Settler identities, historical consciousness and the need for reconciliation. Citizenship Teaching \& Learning, 7(2), 143-156.

Waiser, W. (2005). Saskatchewan: A new history. Calgary, AB: Fifth House. 
Wallis, J. (2011). “Biblical social justice and Glenn Beck.” Huffington Post. Retrieved from http://www.huffingtonpost.com/jim-wallis/biblical-social-justice-a_b_493875.html

Whitlock, R. (2007). Queerly fundamental: Surviving straightness in a rural southern high school. In N. Rodriguez \& W. Pinar (Eds.), Queering straight teachers: Discourse and identity in education (pp. 65-93). New York, NY: Peter Lang.

Whitlock, R. (2010). Getting queer: Teacher education, gender studies, and the cross-disciplinary quest for queer pedagogies. Issues in Teacher Education, 19(2), 81-104.

\section{Appendix A}

\section{Interview Questions}

1. How long have you been a teacher? Where have you taught? What grades and subjects have you taught? In terms of the courses in the Social Sciences, what specific courses and grade levels have you taught?

2. Can you please describe the student population currently served by your school? [Probes: socioeconomic status, cultural diversity, religious influence, percentage of two-parent and one-parent families, etc.]

3. In your opinion, what is the purpose of Social Studies? Do you believe Social Studies to be a political enterprise? Explain.

4. What are your thoughts on the following statement? "Social Studies must prepare students with the duties and responsibilities of citizenship in a democracy."

5. Does religion have any place in Social Studies? Explain.

6. Some teachers think that it is important that they remain neutral, not express their opinion in class, and instead focus on creating an open and supportive environment where students feel free to express their thoughts and feelings. Others, while agreeing that diverse views should get a fair hearing, think that it is important for teachers to clearly articulate their own positions. Where do you stand on this issue? Explain.

7. Do you encourage classroom discussions around controversial issues? (If not), why not? (If so), which ones? Why those ones?

8. What is more important to teach about in Social Studies: rights or responsibilities? Explain.

9. In light of more and more immigrants moving to Saskatchewan, do you think multicultural education should become a more important part of the Social Studies curriculum? What about the ways you teach about issues of race?

10. Do Christian activists such as Tommy Douglas or Martin Luther King enter into your teaching? If so, do you make connections to their Christian backgrounds? Explain.

11. Do you feel that the Social Studies (and/or History) curricula adequately covers the contributions or experiences of Aboriginal peoples? [If not], do you do anything to compensate for this? What? Why? 
12. What does the term social justice mean to you? Do you think the role of the teacher should include encouraging a social justice perspective in students? Do you think charity is enough to help the poor, or should the government step in? Explain.

13. Do you feel that the Social Studies (and/or History) curricula adequately covers the contributions or experiences of the working classes or labour unions? [If not], do you do anything to compensate for this? What? Why?

14. What are your thoughts on economic issues like taxes and tax cuts as well as social welfare programs? Do you cover these topics in your teaching? Explain.

15. Many scholars point out that the Canadian Charter of Rights and Freedoms has strengthened the feminist movement and given rise to the gay rights movement. Do you agree? Do you cover the Charter in your teaching? If so, do you make these connections to feminism and gay rights? Explain. 